Qiu Mubing

Stroganov Moscow State Arts and Industry Academy of

e-mail:493781521@qq.com

Shijiazhuang, China

ORCHID 000-0002-5699-7562

DOI: $10.36340 / 2071-6818-2019-15-4-63-81$

\title{
Statues of Warriors and War Horses of the Han Dynasty
}

Summary. Terracotta statues of warriors and war horses represent a type of sculpture from ancient burials. They are an important part of the system of objects buried together with the deceased during the Han dynasty (the so-called Mintsi). Yun, the most characteristic funeral figurines which archaeologists find especially in the region of the Chu kingdom of the pre-Qin period, began to appear during the Chunqiu and the Warring States periods. The burial of statues of soldiers together with the deceased carried an authentic meaning connected with the burial of living warriors during the Shang dynasty.

Terracotta statues of warriors and war horses in the tomb of Qin Shi Huang were completed in a very short time and mainly reproduced the figures of people and soldiers on high alert before the start of a military campaign. Despite the fact that the Han Dynasty succeeded the Qin Dynasty in the administrative system, it also drew some lessons, to varying degrees, regarding martial arts, as evidenced by the location combinations of the terracotta statues and horses.

In 1965, a large burial place of the ancestor of Liu Bang, the first emperor of the Han dynasty, was discovered in the Shaanxi province north of Xianyang in Yangjiawan village. In history, it was known as Zhoushitsuy or Mound of Zhou Ancestors. The size and

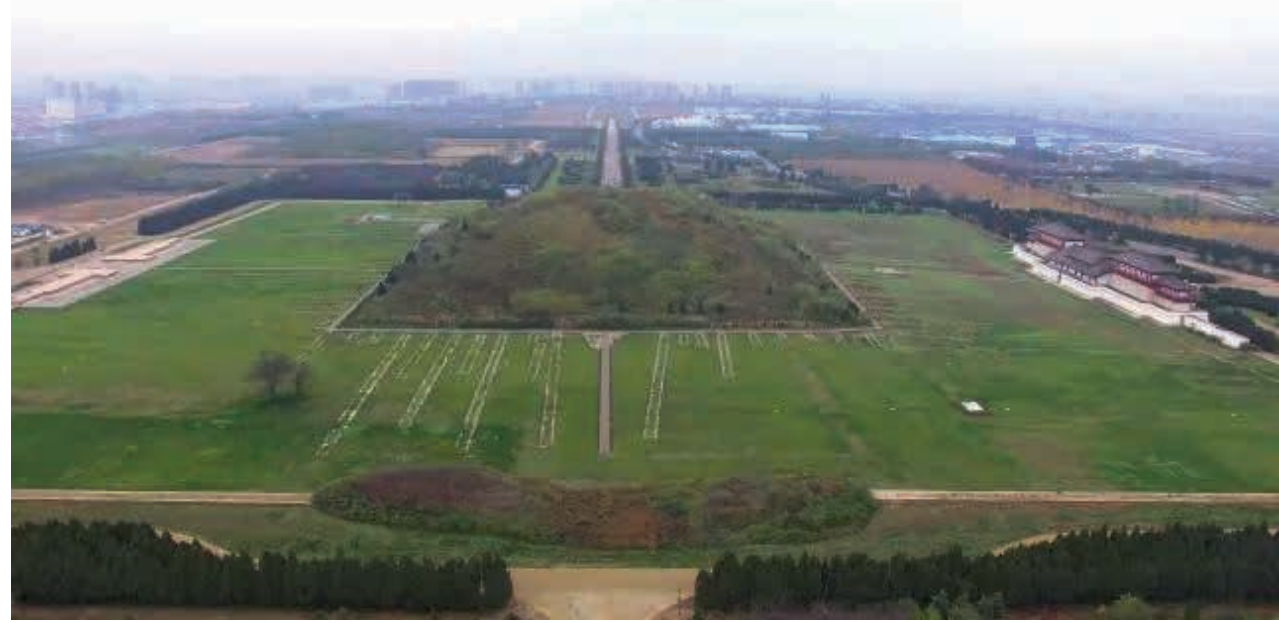

Ill. 1. National architectural monument. Han Dynasty. Mausoleum Han Yang Ling. 


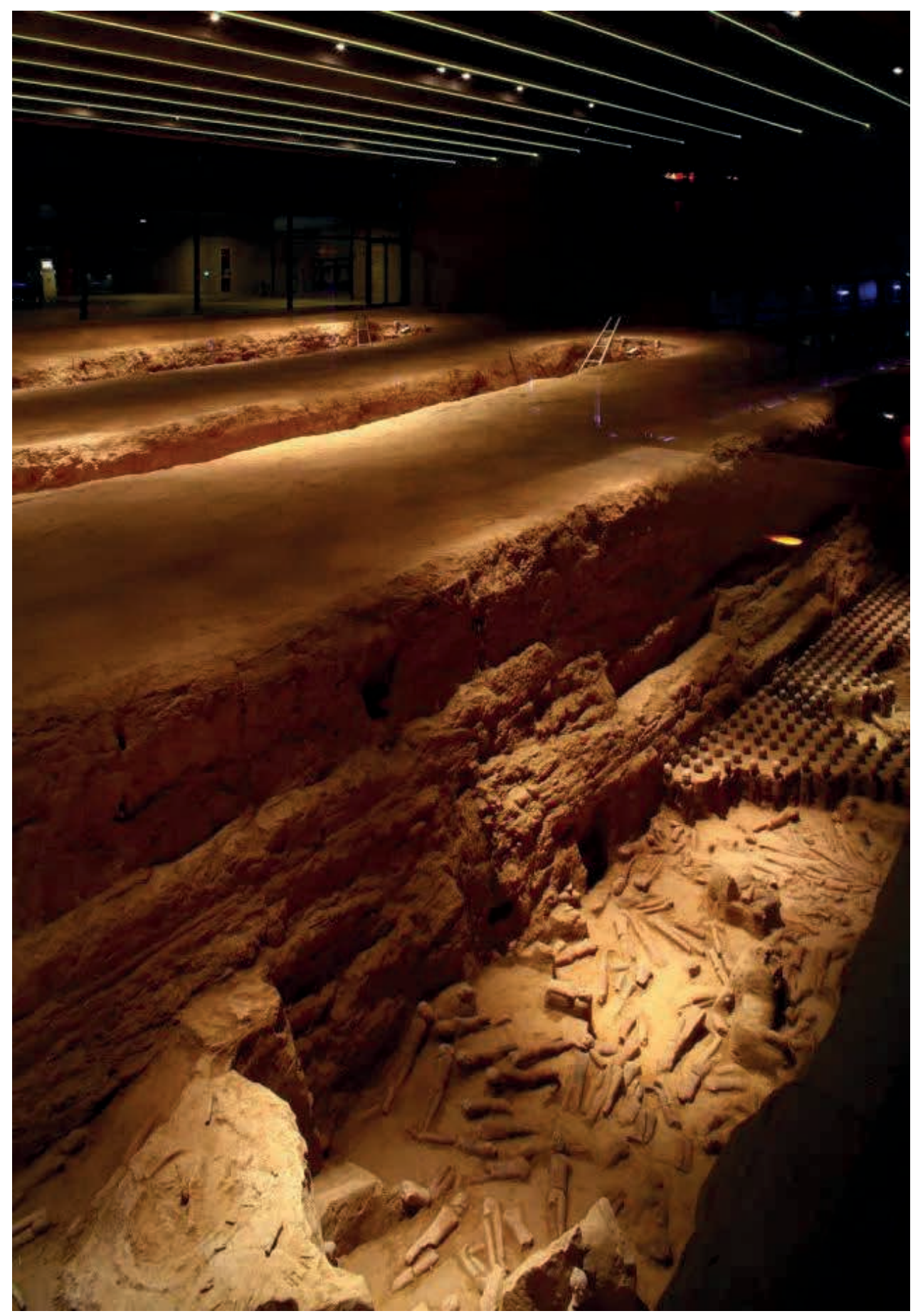

Ill. 2. Grave pits in the Hanyangling Museum 


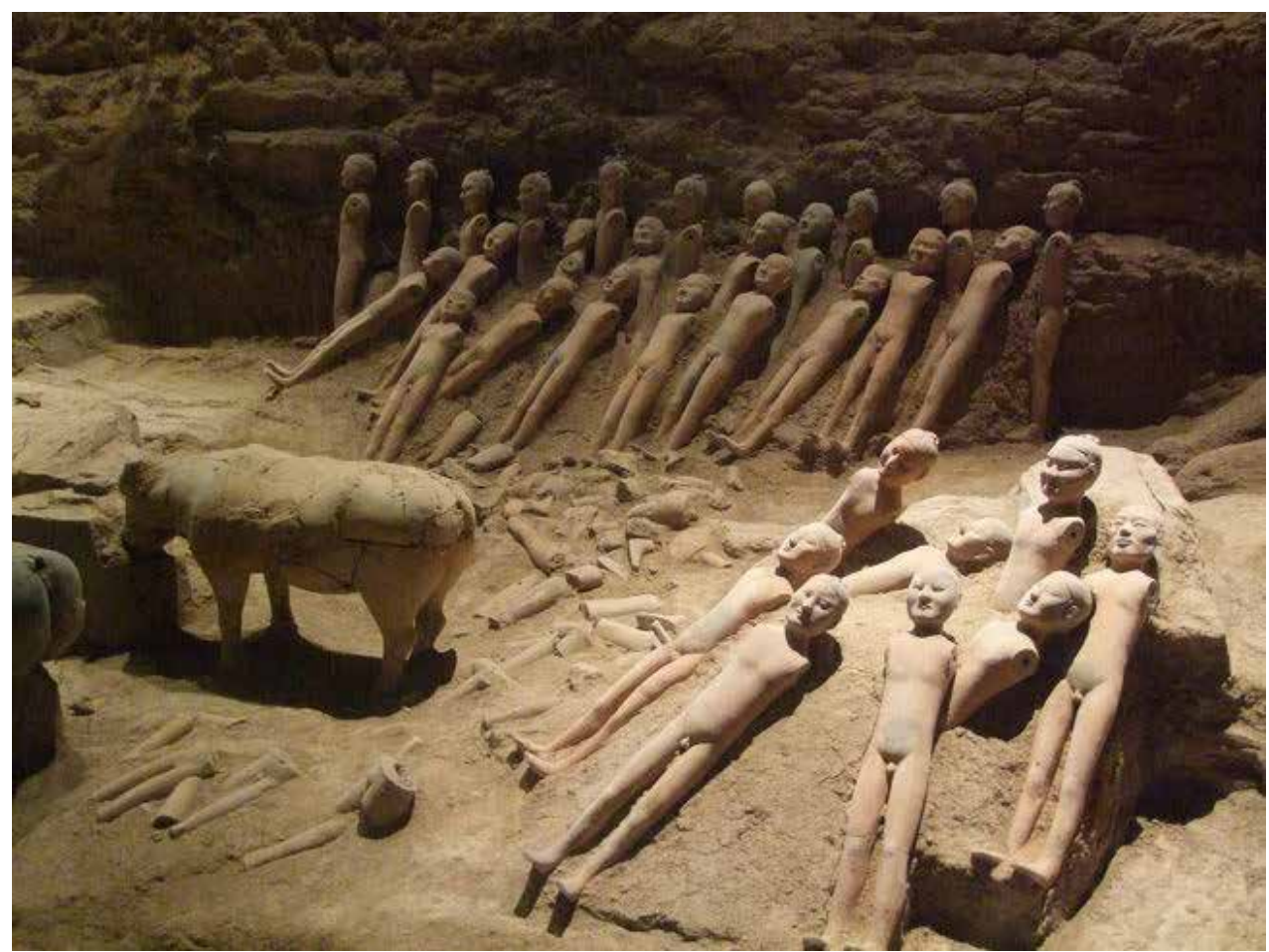

Ill. 3. Excavation. Funerary figures of warriors and horses. The Hanyangling Museum

depth of the pits are not the same, the number of ceramic statues found is also various and of different shapes and sizes; however, most of the statues have a bright colour and a perfectly regular shape. These excavations of the Han terracotta statues have historical significance due to the fact that this is the first finding of terracotta statues of the Han period since the founding of New China.

Key words. Han dynasty, Terracotta statues, China sculpture, statues of warriors

Terracotta statues of warriors and war horses represent a type of sculpture from ancient burials. They are an important part of the system of objects buried together with the deceased during the Han dynasty (the so-called Mintsi, 明器). In ancient times, the burials of living people took place. Slaves were the property of slave owners. After the death of their owners, they had to accompany them to the grave as a funeral attribute. In the Yinxu 1 (殷墟) burial complex, ashes of soldiers sitting and kneeling, holding bronze dummies and shields in their hands (Ill. 1) are found as well as a significant number of war chariots (Ill. 2) and the ashes of people driving them. This indicates that there had already been a culture of the burial of warriors and war horses as funeral implements of the owner of the tomb since the Shang dynasty (1600-1046 BC 商).

1. Yinxu is the ruins of the capital of the late Shang Dynasty, which dates from the late 14 th - early 11th centuries BC. 


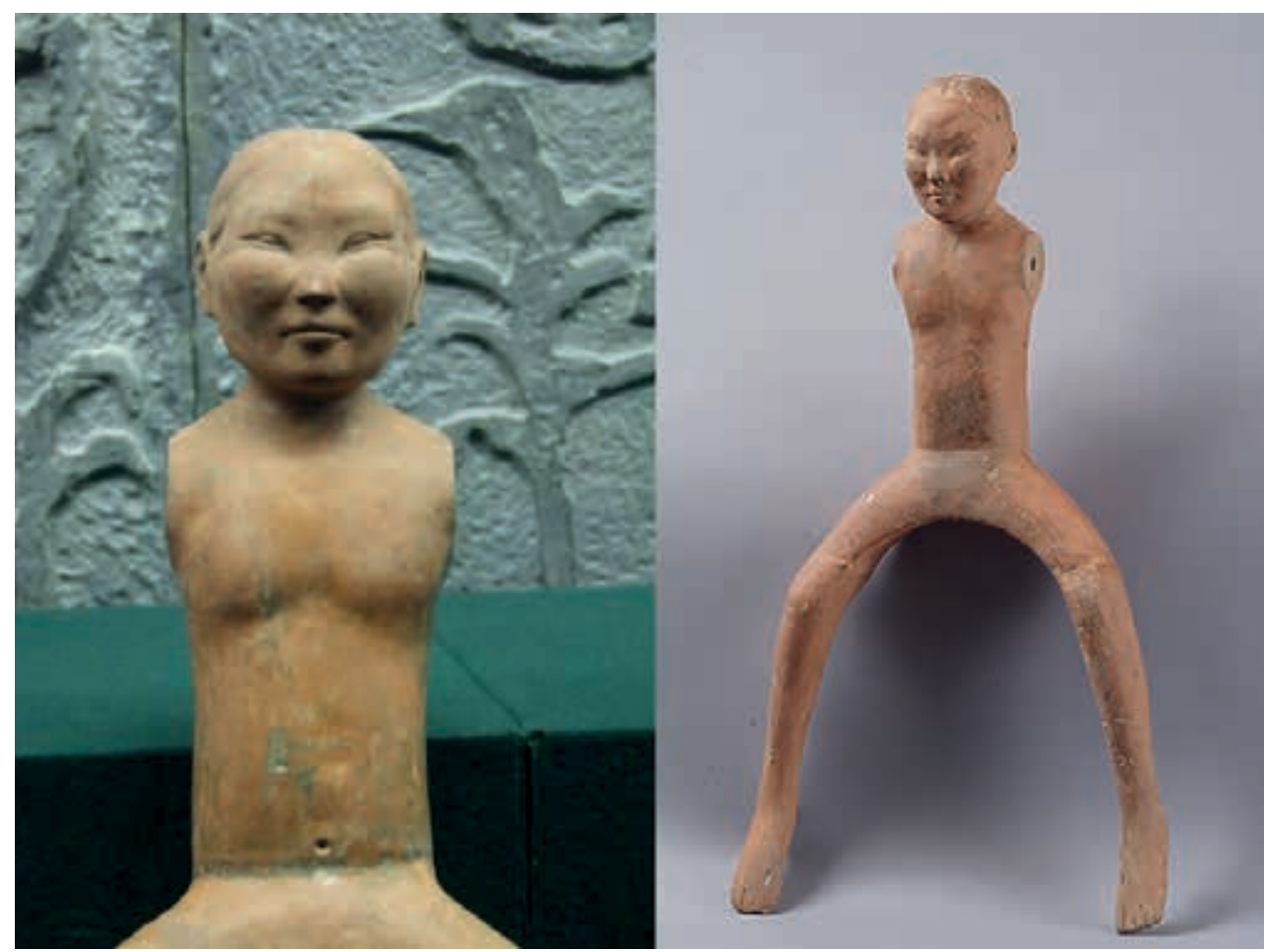

Ill. $12 \square$ Funerary figure of horseman $53 \mathrm{~cm}$.

The Hanyangling Museum

Yun, the most characteristic funeral figurines, which archaeologists find especially in the region of the $\mathrm{Chu}^{2}$ kingdom （楚）(Ill. 3) of the pre-Qin period, began to appear during the Chunqiu and the Warring States periods. The burial of statues of soldiers together with the deceased carried an authentic meaning connected with the burial of living warriors during the era of the Shang dynasty. Nevertheless, it is worth noting that although the statues were made of wood or ceramics, qualitatively or rough, their size is quite small and they differ greatly from the terracotta army of the Qin Dynasty. The terracotta army of the Qin Dynasty is a miracle in the history of sculpture of Chinese burials (Ill. 4) and can be described as unparalleled. Their figurative and realistic method of creation, their human-sized height, a huge and magnificent, as if suddenly arising, military massif added a colourful touch to the history of sculpture of Chinese burials.

Terracotta statues of warriors and war horses in the tomb of Qin Shi Huang (秦始皇) were made in a very short time and mainly reproduced the figures of people and soldiers on high alert before the start of a military campaign. They do not depict the scene of a battle but show the assembled soldiers in the state before it. Their creation was carried out in a combined way using molds and clay sculpting. The produc-

2. The state of Chu (1115-223 BC) is a vassal principality in the Yangtze river basin in the pre-Qing period. 


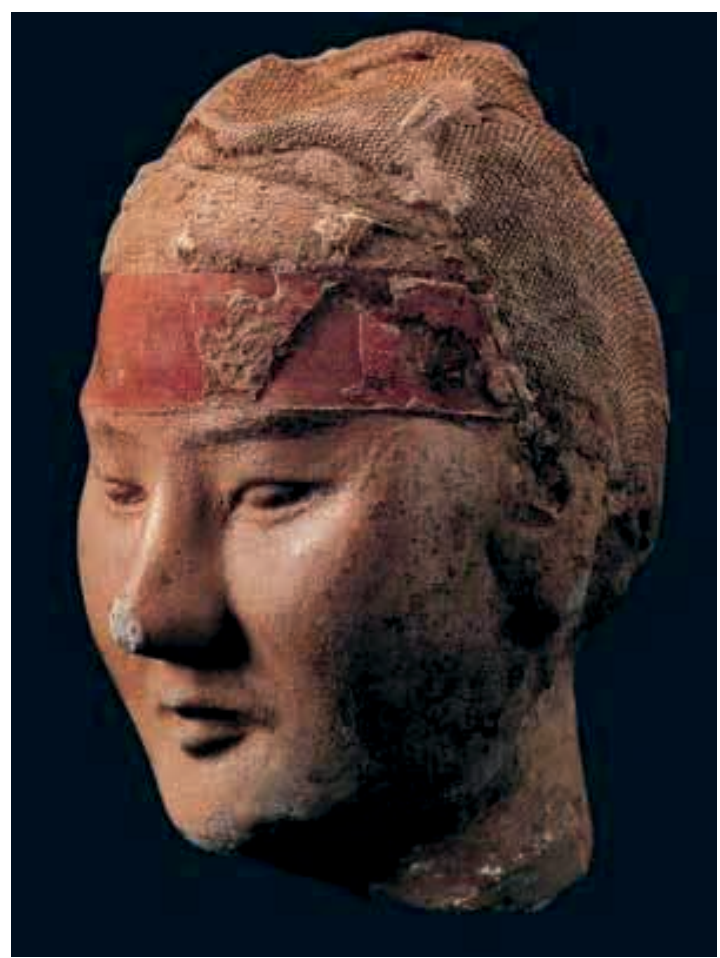

Ill. 4. Red silk (on the forehead) and pieces of textile (on the top of the head) were founded during excavation. The Hanyangling Museum tion was phased, segmented; at first, the base and the approximate form were sculpted which were further refined and carefully detailed using dispersed clay. After firing in the furnace, the figures were painted. Ceramic soldiers and horses are mostly stationary. Repeated many times, artists used this feature of a static pose to demonstrate a huge army the power of which is indestructible. It was supposed to make ordinary mortals feel a sense of awe and humility.

Although the Han Dynasty succeeded the Qin Dynasty in the administrative system, it also drew lessons to one degree or another regarding martial arts as evidenced by the combination of the locations of the terracotta statues and horses. During the Han dynasty, many honoured commanders and generals, princes and aristocrats considered it an honour to be buried with a terra-

cotta army in order to show the lifetime glory and status. Therefore, the number and size of the found terracotta armies is greater than during previous eras. The Yangjiawan graves in Xianyang (咸阳 杨家湾), Jing Di in Yangling (景帝 阳 陵), Shizishan in Xuzhou (徐州 狮子山), Leitai in Wuwei（武 威雷 台) are examples of the burial places of the armies during the Han dynasty.

\section{Yangjiawan Terracotta Army}

In 1965, a large burial place of the ancestor of Liu Bang, the first emperor of the Han dynasty, was discovered in the Shaanxi province north of the city of Xianyang in the village of Yangjiawan. In history, it was known as Zhoushitsuy or Mound of Zhou Ancestors. Experts concluded that the owner of the tomb was most likely Zhou Bo (周勃), a famous early Han dynasty general, and his son Zhou Yafu ${ }^{3}$ (周亚夫).

3. Zhou Yafu was the son of Zhao Bo who made a huge contribution to the formation of a new state and the creation of a new dynasty. Two years later, Han Wen Di would receive the title of prince from his father. 


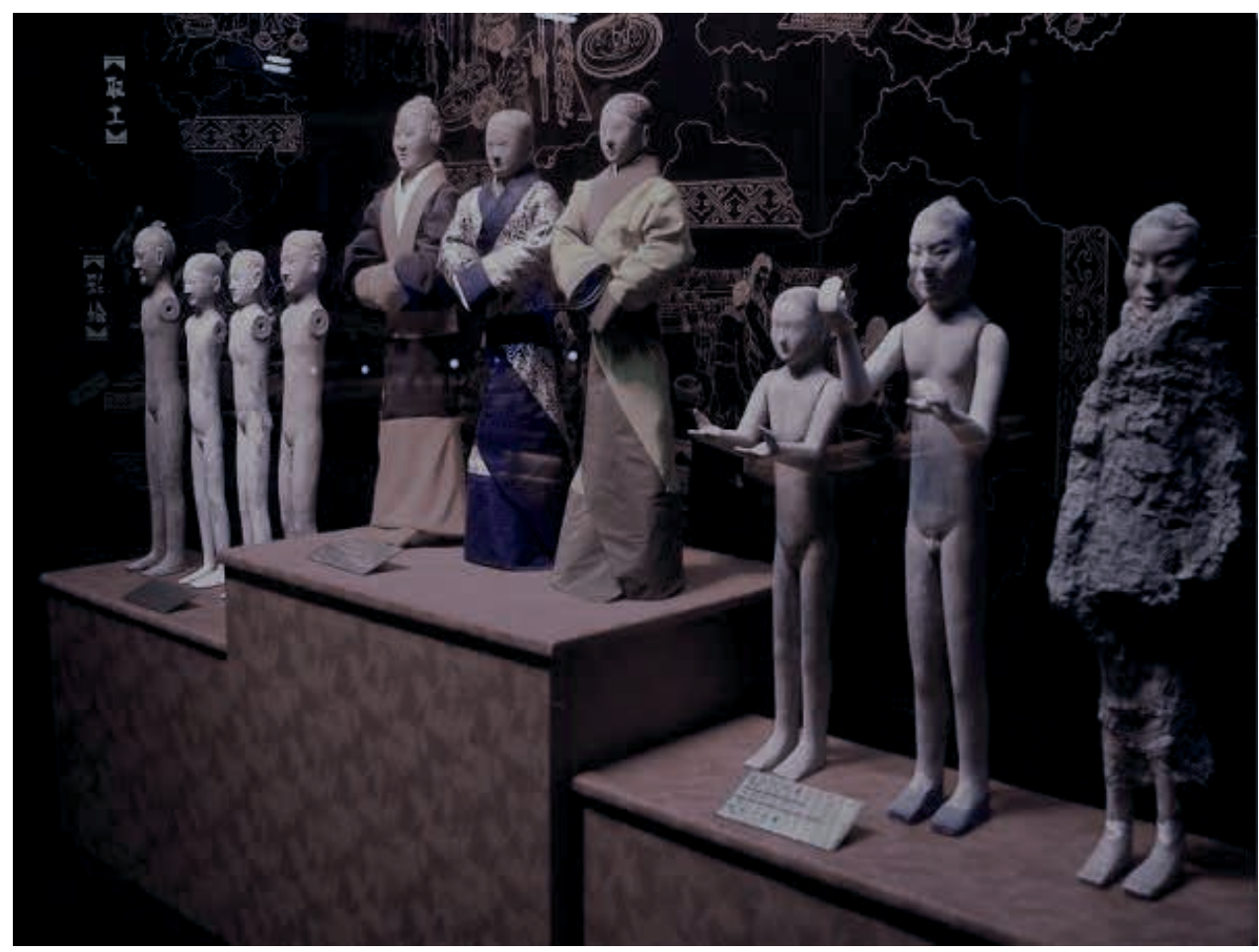

Ill. 5. Ceramic funeral figurines with wooden arms and in clothes. The Hanyangling Museum

There, archaeologists discovered 583 statues of cavalrymen, about 2000 statues of infantrymen (Ill. 5), over a thousand shields and a huge number of arrowheads, triggers, attributes of war chariots, etc. These warriors were divided into thirteen formations and buried in thirteen subsurface caves in ten pits. The burial pits are located from south to north, and the eastern and western two rows are located opposite each other, going vertically downwards. One or two subsurface grottoes were dug in the burial pits in the side walls where troops were placed in rows.

The size and depth of the pits are not the same, the number of ceramic statues found is also various, their variations are different; however, most of the statues have a bright colour and perfectly regular shape. These excavations of Han terracotta statues have historical significance due to the fact that this is the first finding of terracotta statues of the Han period since the founding of New China. These so-called "three thousand fighting soldiers and horses" from the Yangjiawan village were restored by experts in cultural relics, put in order, and started to be officially exhibited attracting the attention of the public.

In addition to the terracotta troops, the Yangjiawan grave also has a small number of statues of civil servants, dancers and musicians, ordinary servants and other statues, the number of which is more than a hundred pieces. Together with the terracotta army, 


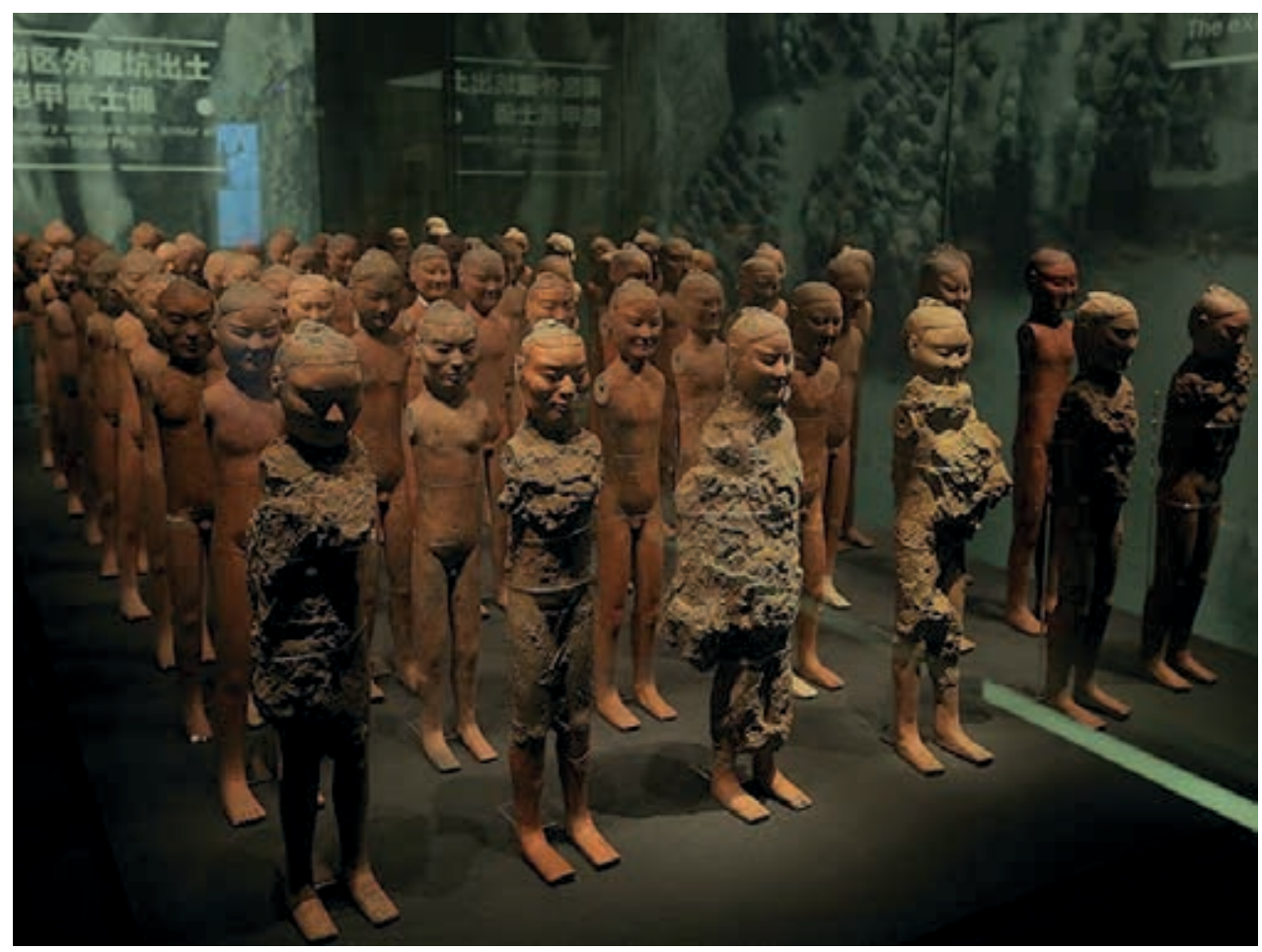

Ill. 6. Funerary figures of warriors in armor. Ceramic, $62 \mathrm{~cm}$. Western Han Dynasty. The Hanyangling Museum

the total number reaches more than 2500 statues. Today, this burial is considered to be the largest burial of the Han Dynasty. Infantrymen and cavalrymen are located in battle order. The height of the infantrymen varies between $44-56 \mathrm{~cm}$, the height of the cavalrymen is $68 \mathrm{~cm}$, all are in the same position and uniform poses.

The use of molds and hand sculpting was the production technology, due to this the whole army has a slender and solemn appearance. However, the face of each figure has unique individual features which also gives the right to say that they have some differences in their unity (Ill. 6). The uniqueness of this terracotta army is that the painting was preserved on the figures after excavation and this is really amazing. The army was painted mainly in black, white, red, yellow, green, purple, brown and other colours. Among other things, armour, sleeves and collars of the standing figures are especially detailed. The painting of hats and boots was also of maximum likeness.

Based on the information obtained during the archaeological excavations, the figures of standing soldiers may be divided into statues holding weapons in their hands or carrying them on their backs, statues holding a banner in their hands (Ill. 7), statues with scrolls, statues of commanders, etc. Everyone has different functions in military affairs. The figures of the soldiers holding weapons in their hands (Ill. 8) occupy the vast majority, their height is approximately $50 \mathrm{~cm}$. As a rule, the right hand is clenched 


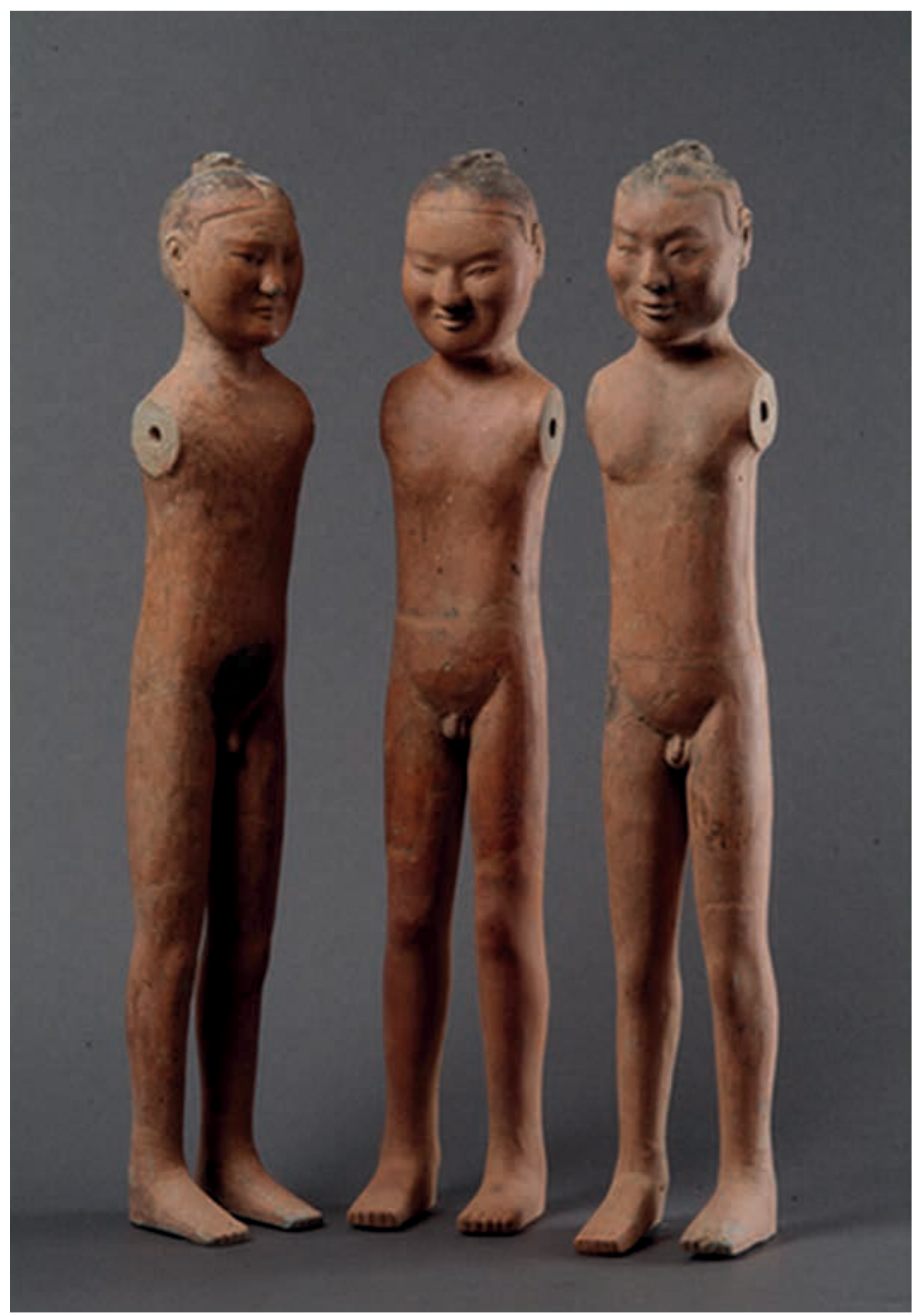

Ill. 7. Funerary naked figures of warriors. Ceramic, $62 \mathrm{~cm}$. Western Han Dynasty. The Hanyangling Museum 

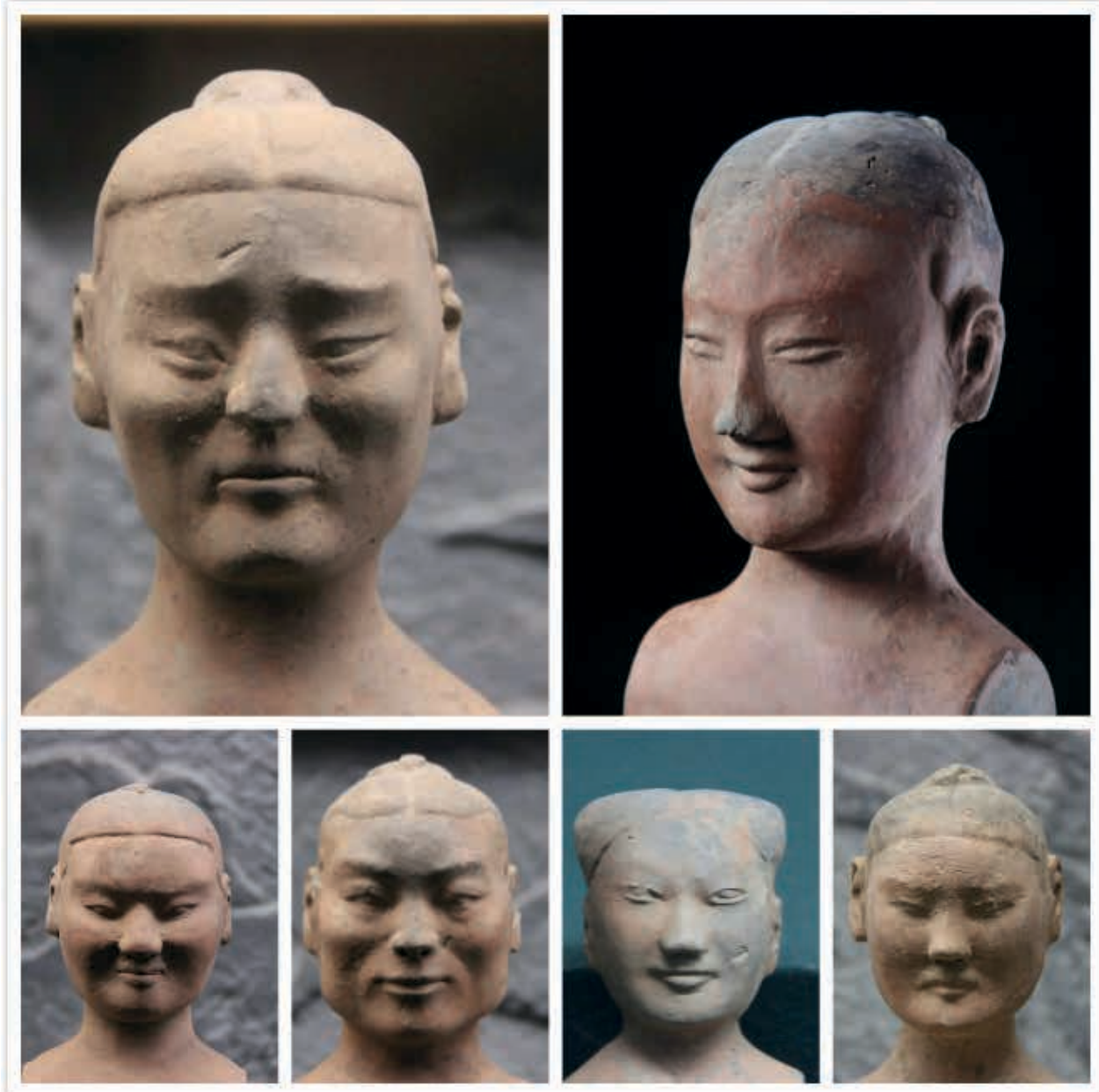

Ill. 8. Portraits of warriors. Ceramic. The Hanyangling Museum

into a fist in a bent state, the left hand may be holding a weapon. A spear has been preserved in the hands of some figures. Many painted shields are found in the burial pit. Before being removed from the ground, they must be attached to the hands of figures. The accountant's statue (Ill. 9) is $48 \mathrm{~cm}$, there is a hat on his slightly lowered head, his gaze is fixed on his hands as if he is making notes. The brush in the right hand might have been made of wood; however, it turned into dust as long time has passed. There are few such statues; they were responsible for the clerical work of the army.

The statue of the commander of the army (Ill. 10) is a sculptural masterpiece among the Yanjiawan terracotta soldiers. Its height is $56 \mathrm{~cm}$ and this is the tallest figure. His equipment is also different from ordinary soldiers. He has a formidable appearance of an army commander. The head is uplifted and slightly bent to the right, the left shoulder is lowered, and the left hand with the rolled-up sleeve is tilted left down, the thumb is 


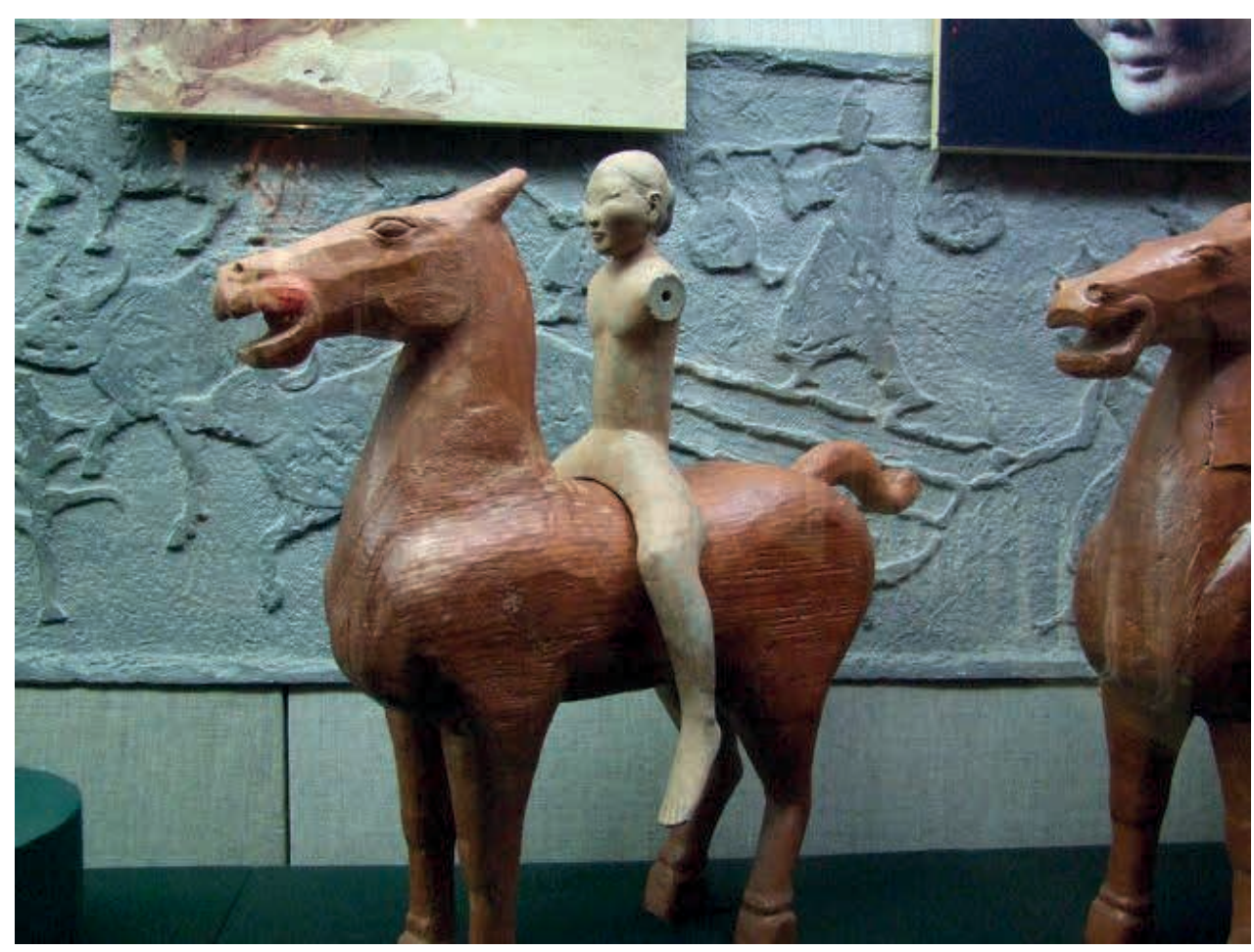

Ill. 8. Renovated funerary figure on the wooden horse. Wood, ceramic. Hight of the figure is $53 \mathrm{~cm}$. Western Han Dynasty.

separated from the four other fingers. The right hand is extended with the index finger, pointing forward. There is a red and brown headwear covering his ears on his head. He is wearing three-layer clothing ${ }^{4}$, leather armour, high moire boots on his feet. This figure is the only and unique statue among the terracotta army. Its physique is the largest among the rest, everything is recreated in the smallest details, it is colourfully painted. Therefore, according to its special position, it is obvious that this is the commander in chief.

In the Yangjiawan burial, the number of statues of horsemen is huge, which indicates that cavalry was already formed as a type of troops and took an important place in the army at the beginning of the Western Han Dynasty. The statues of cavalrymen consist of six groups and are divided into squads of large figures (about $68 \mathrm{~cm}$ ) and squads of small figures (about $50 \mathrm{~cm}$ ). Together with cavalrymen, the statues of infantrymen are synchronously marching in a phalanx formation. They are arranged in various burial graves. The technology of making statues of riders combined the use of molds and hand sculpting, afterwards the statues were fired and then painted. Due to the riding position, the riders' legs were integrated with the horse and made up a single whole. The tail was

4. The usual type of clothing during the Han period. It was customary to wear several layers of clothing. The collar of each layer was to be exposed outward, the largest amount of layers of clothing could be three. 


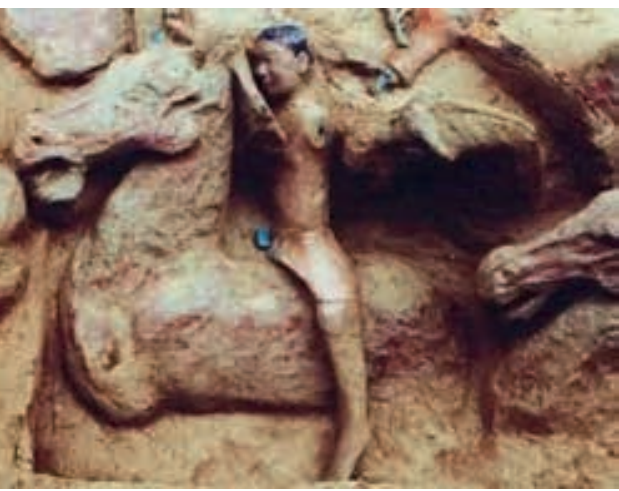

Ill. 10. Funerary figures of horseman. Excavation. The Hanyangling Museum made at the last moment and installed into a special hole.

Judging by the painting of horses, at that time there was still no saddle and stirrups; however, there was already a special brancard protruding outward. This can be seen from the painting on the backs of horses. Over 580 horseback riders, mostly cavalrymen, are lightly armed, without armour and without a quiver on their backs. In the left hand, riders hold the reins, and in the right - a sword. Taking into account the fact that the lower part of a cavalryman's body is the most vulnerable, special knee pads are painted on the legs on the knees. Their shoes also have a painting. The colour of horses is found in three types - black, red, purple. All have special bedding for riders. These large statues of horsemen constitute the main force of the cavalry.

The statues of the small riders are depicted similar to the large ones (Ill. 11); however, there is more white or piebald colour among the war horses. With the exception of the difference in the sizes of the statues of the riders, the difference is also evident in the fact that the small statues of the riders have a quiver for arrows on their backs, which the statues of infantrymen also have. This indicates that this part of the troops is skilled in shooting and can fight at a distance. High maneuverability and speed is an advantage of this kind of troops. The shape of the statues of small horses is also different from the large ones. Large horses are portrayed strong and elevated, the line of the outer contour is energetic. The proportions of small horses are relatively small, their bodies are shorter, the contour line is slim. This was done not because the technique of the sculptors was different, but because these are different types of horses. Sculptors deliberately made them in such a way to make them easy to distinguish.

The achievements of the sculptural art of the Han Dynasty are undeniable, it is also clear that the artistic style of this period is different from the Qin Dynasty. The terracotta army of the Han period was laconic in style, small in size, in a calm state of mind. It resembles traditional Chinese painting style Sei (the free style of "painting ideas") and has a memorable meaning. Despite the fact that the shape of some statues looks a little frozen and does not correspond to the proportions of the human body, you can catch the facial features and emotional changes of the characters between the eyebrows and corners of the mouth (Ill. 12). The faces of the people of the Han Terracotta Army are well thought out and have a realistic foundation. Since China of the Han period had a vast territory, people from different places had their own external features and this is clearly seen from the faces of ceramic statues. 


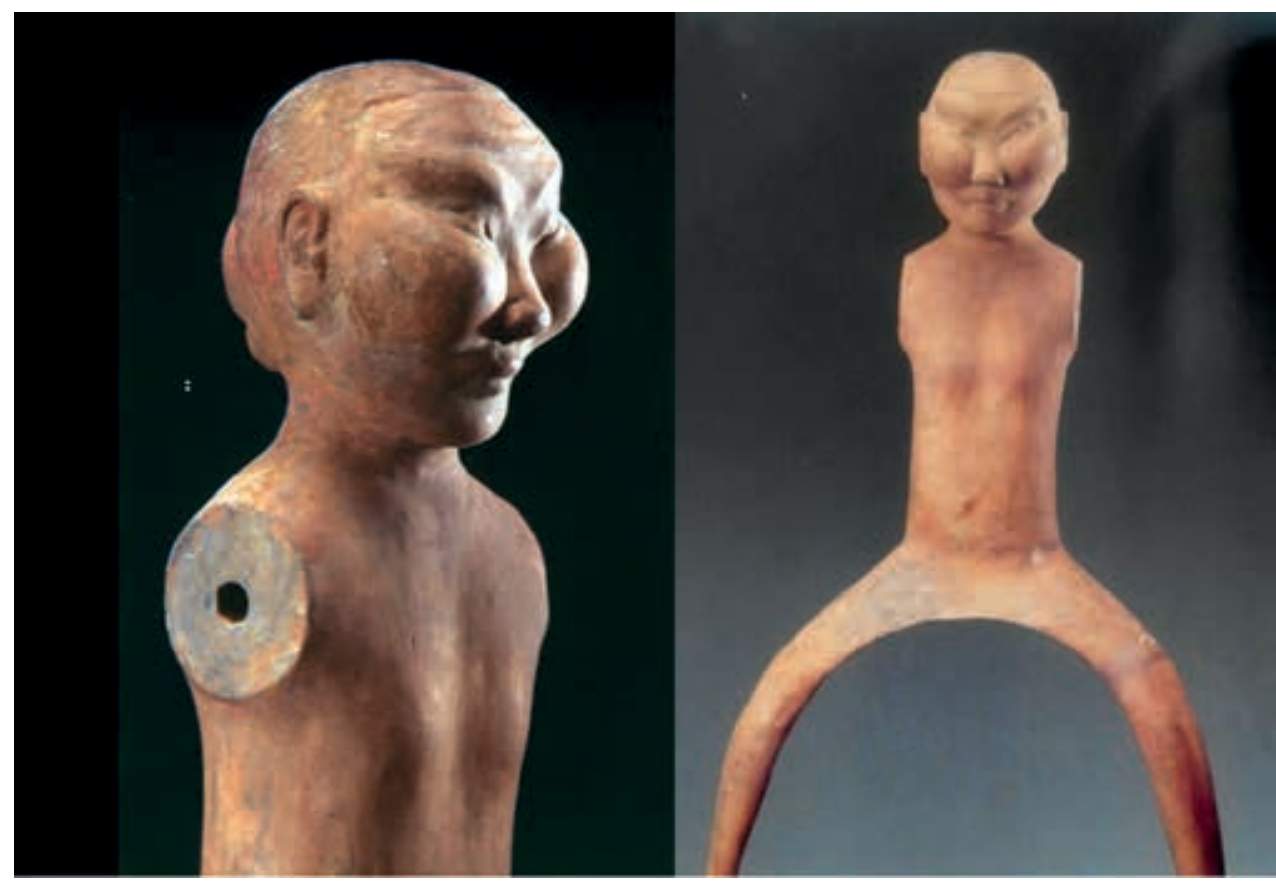

Ill. 11. Funerary figure of horseman. Ceramic. Western Han Dynasty. $53 \mathrm{~cm}$. The Hanyangling Museum

In the early period of Western Han, people believed in the immortality of the soul and therefore worshiped spirits. A record that Liu Bang (刘邦) made "very respectful sacrifices" in relation to his ancestors "and reverently prayed to them" exists in the Historical Notes. Despite the fact that the entire ruling class was madly pursuing luxury and squandering during his lifetime, he was also full of fears and illusions about the posthumous world of spirits. This gives him the opportunity to significantly expand the idea that "death is a continuation of life". The Three Thousand Combat Soldiers and Horses of Yangjiawan are a realistic reflection of this concept. The imitation of real troops and war horses allowed the deceased to have the same glory and position as he had in real life. Thus, buried in the form of a terracotta army in a funerary pit, ceramic soldiers and horses reflect the real number of troops which the deceased could have used during his life. 


\section{REFERENCES}

1. Fan Ye. 2010. (the Liu Song dynasty). The History of the Later Han Dynasty. Zhonghua Book Company Publishing House, Shanghai, p. 3684.

2. Zhao Huacheng and Gao Chongwen. 2002. Archeology of the Qin and Han Dynasties. Beijing: Cultural Relics Publishing House, p 281.

3. Zhang Zhengmin. 1987. The History of Chu Culture. Shanghai: Shanghai People's Publishing House.

4. Wu Mu. 2005. A Study of the Xiongnu History. Beijing: National Publishing House

5. Jian Botsan Jian. 1983. History of the Qin and Han Dynasties. Beijing: Pekin University Publishing House,

6. Huang Jinyang. 1993. The History of the Military Systems of the Qin and Han Dynasties. The Jiangxi People's Publishing House 


$$
\begin{array}{r}
\text { Цю Мубин } \\
\text { Московская государственная } \\
\text { художественно-промышленная академия } \\
\text { им С.Г. Строганова } \\
\text { e-mail: 493781521@qq.сот } \\
\text { г. Шицзячжуан, Китай }
\end{array}
$$

ORCHID 000-0002-5699-7562

DOI: $10.36340 / 2071-6818-2019-15-4-63-81$

\section{Статуи воинов и боевых коней в период ханьской династии}

Аннотащия. Терракотовые статуи воинов и боевых коней являются видом скульптуры древних захоронений и важной составной частью системы погребаемых вместе с покойником предметов в ханьскую эпоху (так называемые «минци»). В период Чуньцю и Сражающихся царств начинают появляться наиболее характерные погребальные статуэтки «юн», которые археологи находят особенно много в районе царства Чу доциньского периода. Захоронение вместе с усопшим статуй солдат имело аутентичный смысл с погребением живых воинов в эпоху периода династии Шан.

Терракотовые статуи воинов и боевых коней в гробнице Цинь Шихуана были сделаны за очень короткий срок и главным образом воспроизводили фигуры людей и солдат в состоянии боевой готовности перед началом похода. Хотя династия Хань преемствует династии Цинь в административной системе, она также в той или иной степени извлекает уроки, касающиеся военного искусства, о чём свидетельствует комбинация расположений терракотовых статуй и коней.

В 1965 г. на территории провинции Шэньси к северу от города Сяньян в деревне Янцзявань было обнаружено крупное захоронение предка Лю Бана, первого императора династии Хань, которое в истории было известно под названием «Чжоушицюй» или «Курган предков Чжоу». Размер и глубина этих ям неодинакова, количество найденных керамических статуй также различно, их разновидность отличается, но большинство статуй имеют яркую окраску и идеально правильную форму. Эти раскопки ханьских терракотовых статуй имеют историческое значение, потому что с момента основания Нового Китая это первая находка терракотовых статуй ханьского периода.

Ключевые слова: терракотовая скульптура, статуи воинов, китайская скульптура, скульптура династии Хань

Терракотовые статуи воинов и боевых коней являются видом скульптуры древних захоронений и важной составной частью системы погребаемых вместе с покойником предметов в ханьскую эпоху (так называемые «минци», 明器). В древние 
времена осуществлялись захоронения живых людей. Рабы были собственностью рабовладельцев и после смерти своего рабовладельца они должны были сопровождать его в могилу в качестве погребального атрибута. В комплексе захоронений Иньсюй $^{1}$ (殷墟) находят прах сидящих и стоящих на коленях солдат, держащих в руках бронзовые клевцы и щиты (рис. 1), значительное количество боевых колесниц (рис. 2), также встречается прах людей, управляющих колесницами. Всё это показывает, что начиная с династии Шан (1600-1046 гг. до н.э. 商) уже существовала культура захоронения воинов и боевых лошадей в качестве погребальной утвари хозяина гробницы.

В период Чуньцю (春秋) и Сражающихся царств начинают появляться наиболее характерные погребальные статуэтки «юн» (俑), которые археологи находят особенно много в районе царства Чу르 (楚) (рис. 3) доциньского периода. Захоронение вместе с усопшим статуй солдат имело аутентичный смысл с погребением живых воинов в эпоху периода династии Шан. Тем не менее, стоит отметить, что несмотря на то, что сделаны статуи из дерева или керамики, качественно или грубо, их размер очень небольшой и они сильно отличаются от терракотовой армии династии Цинь. Терракотовая армия периода эпохи династии Цинь является чудом в истории скульптуры китайских захоронений (рис. 4), о котором можно сказать, что оно не имеет себе равных. Их образно-реалистический метод создания, реальные размеры в человеческий рост, огромный и великолепный военный массив, будто возникший внезапно, добавили красочный штрих в историю скульптуры китайских захоронений.

Терракотовые статуи воинов и боевых коней в гробнице Цинь Шихуана （秦 始皇） были сделаны за очень короткий срок и главным образом воспроизводили фигуры людей и солдат в состоянии боевой готовности перед началом похода. Они не изображают сцену сражения, но показывают собранных солдат в состоянии перед сражением. Их изготовление велось комбинированным способом с использованием пресс-форм и лепки из глины. Производство было поэтапное сегментированное, сперва ваялась основа и примерная форма, которая в дальнейшем уточнялась и тщательно передавалась с помощью дисперсной глины. После обжига в печи фигуры подвергались росписи. Керамические солдаты и кони в основном находятся в неподвижном положении. Мастера-художники использовали эту особенность статической позы, которая многократно повторялась, чтобы продемонстрировать огромную армию, чья мощь несокрушима. Это должно было заставить простых смертных испытывать чувство трепета и смирения.

Хотя династия Хань преемствует династии Цинь в административной системе, она также в той или иной степени извлекает уроки, касающиеся военного

1. Иньсюй - это руины столицы поздней династии Шан, которая датируется концом XIV началом XI вв. до н. э.

2. Государство Чу (1115-223 гг. до н.э.) - вассальное княжество в бассейне реки Янцы в доцинский период. 
искусства, о чём свидетельствует комбинация расположений терракотовых статуй и коней. В ханьский период, чтобы показать прижизненные славу и статус, многие заслуженные главнокомандующие и генералы, князья и аристократы считали за честь быть погребённым с терракотовой армией. Поэтому количество и размеры встречающихся терракотовых армий больше предшествующих эпох. Представителями захоронений армий в ханьскую эпоху являются погребения Янцзявань в Сяньяне（咸阳杨家湾）, Цзин-ди в Янлине（景帝阳陵）, Шицзышань в Сюйчжой (徐州狮子山), Лэйтай в Увэй（武威雷台）.

\section{Терракотовое войско Янизявань}

В 1965 г. на территории провинции Шэньси к северу от города Сяньян（咸阳） в деревне Янцзявань (杨家湾) было обнаружено крупное захоронение предка Лю Бана, первого императора династии Хань, которое в истории было известно под названием «Чжоушицюй» (周氏曲) или «Курган предков Чжоу». Эксперты сделали заключение, что хозяином гробницы скорее всего был известный генерал раннего периода династии Хань Чжоу Бо （周勃） и его сын Чжоу Яфу³ (周亚夫) . Археологи здесь обнаружили 583 статуи кавалеристов, около 2000 статуй пехотинцев (рис. 5), свыше тысячи щитов и огромное количество наконечников стрел, спусковых затворов, атрибутов боевых колесниц и т.д. Эти воины были разделены на тринадцать построений и похоронены в тринадцати грунтовых пещерах в десяти ямах. Погребальные ямы расположены с юга на север, а восточный и западный ряд два ряда расположены друг напротив друга, уходя вертикально вниз. В погребальных ямах в боковых стенах вырывались один или два грунтовых грота, куда были помещены войска в ряды.

Размер и глубина этих ям неодинакова, количество найденных керамических статуй также различно, их разновидность отличается, но большинство статуй имеют яркую окраску и идеально правильную форму. Эти раскопки ханьских терракотовых статуй имеют историческое значение, потому что с момента основания Нового Китая это первая находка терракотовых статуй ханьского периода. Эти так называемые «три тысячи боевых солдат и коней» из деревни Янцзявань были отреставрированы экспертами по культурным реликвиям, приведены в порядок и стали официально экспонироваться, привлекая внимание общественности.

Кроме терракотовых войск в могиле Янцзявань есть также небольшое количество статуй гражданских чиновников, танцоров и музыкантов, обычных слуг и других статуй, которых насчитывается более ста штук. Вместе с терракотовым войском общее количество достигает более 2500 статуй. Это захоронение на сегодняшний

3. Чжоу Яфу - это сын Чжао Бо, который внёс огромный вклад в образование новго государства и создании новой династии. Хань Вэнь-ди через два года получит по наследству от отца титул князя. 
день считается самым крупным погребением времён династии Хань. Пехотинцы и кавалеристы расположены в боевом порядке. Высота пехотинцев варьируется в пределах 44-56 см, высота кавалеристов 68 см, все находятся в одинаковом положении и единообразных позах.

Технология производства заключалась в использовании пресс-форм и ручной лепки, благодаря чему всё войско имеет стройный и торжественный вид. Но лица каждой фигуры обладают уникальными индивидуальными чертами, что также даёт право говорить о том, что в своём единстве они имеют некоторые отличия (рис. 6). Уникальность этого терракотового войска в том, что после раскопок на фигурах сохранилась роспись и это действительно удивительно. Армия была расписана в основном чёрными, белыми, красными, жёлтыми, зелёными, фиолетовыми, коричневыми и другими красками. Среди прочего особенно подробно расписаны доспехи, рукава и воротники стоящих фигур. Максимальное сходство также имела роспись головных уборов и сапог.

На основе информации, полученной в ходе раскопок, фигуры стоящих солдат можно разделить на статуи, которые держат оружие в руках или несут его на спине, статуи, которые держат в руках знамя (рис. 7), статуи со свитками, командиров и др. Их функции в воинской деле у всех различные. Фигуры солдат, держащих в руках оружие (рис. 8), занимают подавляющее большинство, их высота составляет примерно 50 см. Как правило, правая рука сжата в кулак в полусогнутом состоянии, левая рука может держать оружие. В руках некоторых фигур сохранилось копьё. В погребальной яме встречается много расписанных щитов, которые прежде чем извлечь из под земли необходимо прикрепить к рукам фигур. Статуя бухгалтера (рис. 9) составляет 48 см, голова его в шапке и слегка опущена, взгляд устремлён на руки как будто он делает записи. Кисть в правой руке возможно была сделана из дерева, но из-за долгого времени превратилась в труху. Таких статуй немного, они отвечали за делопроизводство армии.

Статуя командира войска (рис. 10) представляет собой скульптурный шедевр среди терракотовых солдат Янцзявань. Высота его 56 см и это самая высокая фигура. Его экипировка также отличается от обычных солдат. У него грозный вид командующего армией. Голова вздёрнута вверх и немного вправо, левое плечо опущено, а левая рука с засученным рукавом откинута влево вниз, большой палец руки отделён от четырёх других пальцев. Правая рука вытянута с указательным пальцем, указывая вперёд. На голове красно-бурый головной убор, закрывающий уши. На нём трёхслойная одежда ${ }^{4}$, кожаные доспехи, на ногах высокие муаровые сапоги. Эта фигура единственная и уникальная в своём роде статуя среди терракотовой армии. Её телосложение самое крупное среди остальных, все её детали

4. Привычный вид одежды в ханьский период. Было принято надевать несколько слоёв одежды. Воротник каждого слоя должен был оголяться наружу, самое большое количество могло составлять три слоя одежд. 
воссозданы в мельчайших подробностях, она красочно расписана. Поэтому по её особому положению очевидно, что это главнокомандующий.

Количество статуй всадников в погребальном захоронении Янцзявань огромно, что свидетельствует о том, что в начале периода династии Западной Хань уже сложилась кавалерия как вид войск и заняла важное место в армии этого периода. Статуи кавалеристов состоят из шести групп и делятся на отряды из крупных фигур (около 68 см) и отряды из небольших фигур (около 50 см). Статуи из пехотинцев синхронно идут в фаланге вместе с кавалеристами. Расставлены они в различных погребальных захоронениях. Технология изготовления статуй всадников сочетала в себе использование пресс-форм и ручной лепки, после чего статуи обжигались и затем расписывались. Ноги всадников из-за положения верхом на коне были интегрированы с лошадью и составляли единое целое. Хвост изготавливался в последний момент и устанавливался в специальное отверстие.

Судя по росписи лошадей, в то время не было ещё седла и стремян, но уже имелась специальная подстилка, которая выступала наружу. Это видно из росписи на спинах коней. Свыше 580 всадников верхом на лошади, но большинство кавалеристов легко вооружены, без доспехов и без колчана на спине. Всадники в левой руке держат поводья, а в правой меч. Принимая во внимание то, что нижняя часть тела кавалеристов является наиболее уязвимой, поэтому на ногах в местах колен нарисованы и расписаны специальные наколенники. Их обувь также имеет роспись. Цвет лошадей встречается трёх видов - чёрный, красный, фиолетовый. На всех имеются специальные подстилки для всадников. Эти большие статуи всадников составляют главную силу кавалерии.

Статуи маленьких всадников изображены похожими на больших (рис. 11), но среди боевых коней встречается больше белого, либо пегого раскраса. За исключением разницы в размерах статуй всадников, также очевидна разница в том, что у маленьких статуй всадников на спине есть колчан для стрел, который также есть у статуй пехотинцев. Это свидетельствует о том, что эта часть войск искусна в стрельбе и может вести бой на расстоянии. Высокая маневренность и скорость является преимуществом этого рода войск. Форма статуй маленьких лошадей также отличается от больших. Большие лошади переданы сильными и возвышенными, где линия внешнего контура энергичная. Пропорции маленьких лошадей относительно небольшие, их корпус более короткий, контурная линия отличается стройностью. Это сделано не потому, что техника мастеров-ваятелей отличалась, а потому что это разные виды лошадей. И чтобы их легко было различить, скульпторы умышленно сделали их такими.

Достижения скульптурного искусства ханьской династии неоспоримы, очевидно также, что художественный стиль этого периода отличается от циньской эпохи. Терракотовое войско ханьского периода было лаконично по стилю, небольшое по размеру, спокойно по состоянию духа. Оно напоминает традиционную китайскую живопись «сеи» (свободный стиль «живописи идей») и имеет памятное значение. 
Несмотря на то, что форма некоторых статуй выглядит немного застывшей и не соответствует пропорциям человеческого тела, тем не менее можно уловить особенности черт лица и эмоциональные изменения персонажей между бровями и уголками рта (рис. 12). Лица людей ханьской терракотовой армии полностью продуманы и имеют реалистическую основу. Поскольку Китай ханьского периода обладал обширной территорией, люди из разных мест имели свои внешние особенности и это хорошо видно из лиц керамических статуй.

В ранний период Западной Хань все люди верили в бессмертие души и поэтому почитали духов. В «Исторических записках» также есть запись о том, что Лю Бан (刘邦) по отношению к предкам делал «очень почтительные жертвоприношения и благоговейно молился им». Хотя весь правящий класс безумно гонится за роскошью и расточительством при жизни, одновременно с этим он также полон страхов и иллюзий по поводу посмертного мира духов. Это даёт ему возможность значительно расширить представления о том, что «смерть - продолжение жизни». «Три тысячи боевых солдат и коней» Янцзяваня - реалистическое отражение этой концепции. Имитация реальных войск и боевых коней позволяют покойному иметь такую же славу и положение как и при жизни. Таким образом, керамические солдаты и кони захороненные в виде терратовой армии в погребальной яме, отражают реальное количество войск, которое мог задействовать усопший при жизни.

\section{БИБЛИОГРАФИЯ}

1. Фан Е (династия Южная Сун). 2010. История династии Поздняя Хань. г. Шанхай. Издательство «Книжная компания Чжунхуа», 2010 г. С. 3684.

2. Чжао Хуачэн и Гао Чонгвен. 2002. Археология в династии Цинь и Хань. г.Пекин. Издательство «Культурные реликвии». 2002 г. С. 281.

3. Чжан Чжэнмин. 1987. История культуры иарства Чу. г.Шанхай. Издательство «Шанхайское Народное».1987 г.

4. Ву Му. 2005. Исследование истории Сюнну. г.Пекин. Издательство «Национальное Издательство». 2005г.

5. Цзянь Боцань Цзянь. 1983. История династий Цинь и Хань. г.Пекин. издательство «Пекинского университета», 1983 г.

6. Хуан Цзиньян. 1993. История военных систем династий Цинь и Хань. Издательство «Цзянсиское Народное издательство». 1993 г. 